\title{
Kesesuaian Pengaturan Pemanfaatan Zona Migrasi Biota Laut dalam Peraturan- Peraturan Daerah Provinsi dengan UU tentang Pengelolaan Wilayah Pesisir dan Pulau-Pulau Kecil (UU WP3K) \\ Dalila Doman ${ }^{1}$
}

\section{Pendahuluan}

Wilayah pesisir dan pulau-pulau kecil (WP3K) merupakan ruang lautan yang masih dipengaruhi oleh kegiatan di daratan dan ruang daratan yang masih terasa pengaruh lautnya, serta pulaupulau kecil dan perairan sekitarnya yang merupakan satu kesatuan dan mempunyai potensi cukup besar yang pemanfaatannya berbasis sumber daya, lingkungan dan masyarakat. ${ }^{2}$ UU No. 27 Tahun 2007 juncto UU No. 1 Tahun 2014 tentang Pengelolaan Wilayah Pesisir dan PulauPulau Kecil (UU WP3K) adalah regulasi pengelolaan WP3K yang meliputi salah satunya kegiatan koordinasi perencanaan sumber daya WP3K dan proses alamiah, secara berkelanjutan. ${ }^{3}$ Salah satu tahap perencanaan pengelolaan WP3K adalah rencana zonasi wilayah pesisir dan pulau-pulau kecil (RZWP3K). ${ }^{4}$
RZWP3K adalah rencana penentuan arah penggunaan dan pemanfaatan sumber daya di tiap satuan perencanaan, disertai dengan penetapan struktur dan pola ruang pada kawasan perencanaan yang memuat kegiatan yang "boleh dilakukan", "tidak boleh dilakukan" dan "kegiatan yang hanya dapat dilakukan setelah memperoleh izin". 5 UU WP3K mengamanatkan RZWP3K ditetapkan dengan peraturan daerah (perda). ${ }^{6}$ Dorongan penetapan Perda RZWP3K disampaikan melalui Surat Dirjen Pengelolaan Ruang Laut No. B-962/PRL/ XI/2016 tanggal 23 November 2016 perihal Akselerasi Penetapan Perda RZWP3K. Provinsi yang telah mengesahkan Perda RZWP3K berjumlah Provinsi tersebut adalah Gorontalo, Jawa Barat, Jawa Tengah, Jawa Timur, Kalimantan Barat, Kalimantan Selatan, Kalimantan Tengah. Kalimantan Utara, Lampung,

\footnotetext{
${ }^{1}$ Penulis merupakan peneliti Indonesian Center for Environmental Law (ICEL) di bidang Pesisir dan Maritim.

${ }^{2}$ Indonesia, Undang-Undang tentang Pengelolaan Wilayah Pesisir dan Pulau-Pulau Kecil, UU No. 27 tahun 2007, LN Tahun 2007 No. 84, TLN No. 4739, Paragraf Pertama Penjelasan Pasal 2.

${ }^{3}$ Indonesia, Undang-Undang Perubahan Atas Undang-Undang No. 27 Tahun 2007 tentang Pengelolaan Wilayah Pesisir dan Pulau-Pulau Kecil, UU No. 1 Tahun 2014, LN Tahun 2014 No. 2, TLN No. 5490, Pasal 1 angka 1 dan Indonesia, Op. Cit., Pasal 5.

${ }^{4}$ Ibid., Pasal 7 ayat (1) huruf b dan Penjelasan I. Umum, 3. Ruang Lingkup, a. Perencanaan.

${ }^{5}$ Indonesia, Op. Cit., Pasal 1 angka 14 dan Indonesia, Op. Cit., Pasal 9 ayat (1).

${ }^{6}$ Ibid., Pasal 9 ayat (5) dan Indonesia, Undang-Undang No. 23 Tahun 2014 tentang Pemerintah Daerah, UU No. 23 Tahun 2014, LN Tahun 2014 No. 244, TLN No. 5587, Pasal 27 ayat (3) dan Lampiran huruf Y angka 1.
} 
Maluku, Maluku Utara, NTB, NTT, Sulawesi Barat. Sulawesi Selatan, Sulawesi Tengah, Sulawesi Tenggara, Sulawesi Utara, Sumatera Barat, Sumatera Utara dan D.I Yogyakarta, ${ }^{7}$ dan Bengkulu. ${ }^{8}$ RZWP3K sebagai arahan pemanfaatan sumber daya WP3K spasial ${ }^{9}$ berada di tingkat pemerintah provinsi diwujudkan dalam alokasi ruang. Alokasi ruang merupakan pendistribusian peruntukan ruang di WP3K yang terdiri dari beberapa kawasan. Berikut bagan alokasi ruang RZWP3K:

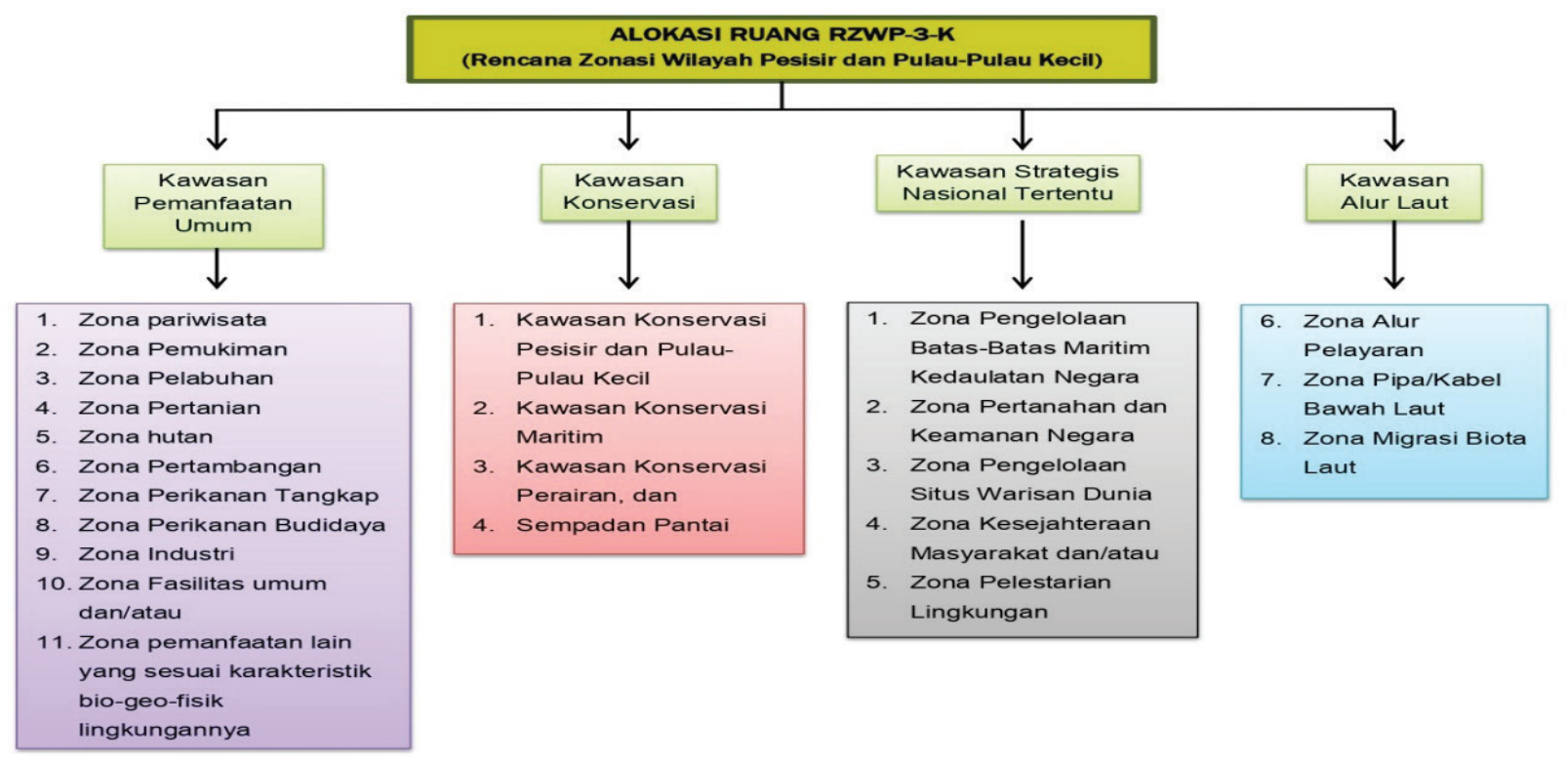

Gambar 6. Alokasi Ruang RZWP-3K ${ }^{10}$

${ }^{7}$ Seanode (FGeoportal RZWP-3-K Online), Status Penyusunan RZWP-3-K 34 Provinsi, Update per bulan Agustus 2019, https://seanode.id/status/, diakses pada 20 November 2019.

${ }^{8}$ Provinsi Bengkulu, Peraturan Daerah Provinsi Bengkulu No. 5 Tahun 2019 tentang Rencana Zonasi Wilayah Pesisir dan Pulau-Pulau Kecil Provinsi Bengkulu Tahun 2019-2039, Perda Provinsi Bengkulu No. 5 Tahun 2019, LD Provinsi Bengkulu Tahun 2019 No. 5, No. Reg. Perda Provinsi Bengkulu: 5-133/2019, TLD Provinsi Bengkulu No. 5.

9 spasial/spa si al/ a berkenaan dengan ruang atau tempat, https://kbbi.web.id/ spasial, diakses pada 28 November 2019.

${ }^{10}$ Kawasan pemanfaatan umum, kawasan strategis nasional, kawasan konservasi dan kawasan alur laut. Tiap kawasan terbagi menjadi beberapa zona: Kementerian Kelautan dan Perikanan, Pedoman Teknis Penyusunan RZWP-3-K (Rencana Zonasi Wilayah pesisir dan Pulau-Pulau Kecil) Provinsi, Kementerian Kelautan dan Perikanan, Direktorat Jenderal kelautan pesisir dan Pulau-Pulau Kecil, Direktorat Tata Ruang laut Pesisir dan Pulau-Pulau Kecil, 2013, Bab II "Ketentuan Teknis Muatan RZWP-3-K Provinsi", 2.3 "Rencana Alokasi Ruang WP-3-K Provinsi", hlm. II-5 - II-6, http://www.tataruangpertanahan.com/file_peraturan/781243110999-Pedoman-Teknis-Penyusunan-RZWP3K-Provinsi.pdf, diakses pada 27 November 2019. 
Kesesuaian Pengaturan Pemanfaatan Zona Migrasi Biota Laut dalam PeraturanPeraturan Daerah Provinsi dengan UU tentang Pengelolaan Wilayah Pesisir dan Pulau-

Pulau Kecil (UU WP3K)

Salah satu zona dalam kawasan alur laut adalah zona migrasi biota laut. Zona migrasi biota laut merupakan suatu area perairan yang dimanfaatkan untuk migrasi atau berpindahnya jenis dan spesies ikan dan mamalia tertentu secara berkelanjutan. ${ }^{11}$ Perda RZWP3K memiliki klausul pengaturan pemanfaatan di zona migrasi biota laut. Tulisan ini akan fokus membahas terkait klausul pengaturan pemanfaatan alur/zona migrasi biota laut dalam Perda RZWP3K.

\section{Zona Migrasi Biota Laut dalam UU WP3K}

Migrasi adalah perpindahan hewan dari satu tempat ke tempat lain dalam suatu alur, hewan tersebut misal burung atau ikan. ${ }^{12}$ Zona (atau dalam beberapa perda disebut alur) migrasi ikan merupakan pola migrasi yang dipengaruhi suhu, salinitas, kecepatan dan arah arus, pasang surut, tinggi dan panjang gelombang, warna perairan, substrat dasar, kedalaman perairan dan tipologi kelandaian dasar laut. ${ }^{13}$ Beberapa hewan bermigrasi di wilayah pesisir. Ekosistem di wilayah pesisir adalah, lahan basah, mangrove, terumbu karang, padang lamun, gumuk pasir, estuari dan delta. ${ }^{14}$ Wilayah pesisir digunakan oleh beberapa ikan seperti ikan karang untuk bermigrasi. ${ }^{15}$ Berbagai jenis ikan hidup di habitat mangrove dan mengalami perpindahan ontogenetic seiring dengan perkembangan stadia hidupnya. ${ }^{16}$

Melihat kerangka dari semua Perda RZWP3K yang telah disahkan, pemanfaatan zona migrasi biota laut diatur dalam klausul tersendiri. Pasal 1 angka 14 UU WP3K mengatur bahwa rencana zonasi menentukan arah penggunaan sumber daya tiap-tiap satuan perencanaan diser-

${ }^{11}$ Ndaru_prasetyo, Maluku Alur Migrasi Mamalia Laut, Seanode (Geoportal RZWP-3-K Online), Direktorat Perencanaan Ruang Laut, Direktorat Jenderal Pengelolaan Ruang Laut, Kementerian Kelautan dan Perikanan, Indonesia, 4 Oktober 2018, https://seanode.id/layers/geonode\%3Amaluku_al_amb, diakses pada 28 November 2019.

12 Dewan Perwakilan Rakyat Republik Indonesia, Proses Pembahasan Rancangan Undang-Undang tentang Pengelolaan Wilayah Pesisir dan Pulau-Pulau Kecil: Buku 1, Sekretariat Jenderal Dewan Perwakilan Rakyat Republik Indonesia, 2008, hlm. 51

${ }^{13}$ Kementerian Kelautan dan Perikanan, Pedoman Teknis Penyusunan RZWP-3-K (Rencana Zonasi Wilayah pesisir dan Pulau-Pulau Kecil) Provinsi, Op-Cit,.... hlm. III-23.

${ }^{14}$ Indonesia, Op.Cit., Pasal 31 ayat 2 huruf d.

15 Oropeza et al. 2009; Kimrei et al. 2011 dikutip kembali oleh Muhammad Nur Findra, La Ode Hasrun, Nadya Adharani dan lela Herdiana (Mahasiswa Sarjana Institut Pertanian Bogor), Perpindahan Ontogenetik Habitat Ikan di perairan Ekosistem Hutan Mangrove, 9 Februari 2017, Media Konservasi Vol. 21, No. 3 Desember 2016 (hlm. 304-309), hlm. 305, https://media.neliti.com/media/publications/231415perpindahan-ontogenetik-habitat-ikan-di-3e962935.pdf, diakses pada 28 November 2019.

${ }^{16}$ Muhammad Nur Findra, La Ode Hasrun, Nadya Adharani dan lela Herdiana (Mahasiswa Sarjana Institut Pertanian Bogor), Perpindahan Ontogenetik Habitat Ikan di perairan Ekosistem Hutan Mangrove, 9 Februari 2017, Media Konservasi Vol. 21, No. 3 Desember 2016, hlm. 308, https://media.neliti.com/ media/publications/231415-perpindahan-ontogenetik-habitat-ikan-di-3e962935.pdf, diunduh pada 28 November 2019. 
tai dengan penetapan struktur dan pola ruang pada kawasan perencanaan ruang memuat kegiatan yang "boleh", "tidak boleh" dan "hanya dapat dilakukan setelah memperoleh izin".

Perda RZWP-3-K yang menetapkan zona migrasi laut dalam lingkup kawasan alur laut, idealnya memiliki pengaturan pemanfaatan zona migrasi biota laut sesuai dengan Pasal 1 angka 14 UU WP-3-K yakni memuat ketentuan mengenai kegiatan yang "boleh”, " tidak boleh" dan "hanya dapat dilakukan setelah memperoleh izin" atas zona migrasi biota laut.

\section{Pengaturan Pemanfaatan Zona Migrasi Laut dalam Perda RZWP-3-K}

Dalam praktiknya, tidak semua Perda RZWP3K menetapkan zona migrasi laut dalam ketentuan alur laut. Penulis membagi Perda tersebut ke dalam 3 (tiga) kategori, yaitu: yang tidak menetapkan alur/zona migrasi biota laut, yang mene- tapkan dan mengatur pemanfaatan migrasi biota laut sesuai dengan UU WP3K, dan yang menetapkan namun pengaturannya kurang sesuai dengan UU WP3K.

A. Perda yang Tidak Menetapkan Alur/Zona Migrasi Biota Laut dalam Lingkup Kawasan Alur Laut

Perda RZWP3K Provinsi Yogyakarta, Perda RZWP3K Provinsi Sumatera Barat, Perda RZWP3K Provinsi Sumatera Utara, Perda RZWP3K Provinsi Kalimantan Barat ${ }^{17}$ dan Perda RZWP3K Provinsi Bengkulu tidak mencantumkan zona migrasi biota laut dalam ketentuan alur laut.

B. Perda yang Menetapkan dan Mengatur Pemanfaatan Migrasi

Biota Laut dalam Perda RZWP3K Sesuai dengan Pasal 1 angka 14 UU WP3K

Perda RZWP3K Provinsi Jawa Timur ${ }^{18}$, Perda RZWP3K Provinsi Jawa Tengah $^{19}$, Perda RZWP3K Provinsi Su-

${ }_{17}$ Provinsi Kalimantan Barat, Peraturan Daerah Provinsi Kalimantan Barat No. 1 Tahun 2019 tentang Rencana Zonasi Wilayah Pesisir dan Pulau-Pulau Kecil Provinsi Kalimantan Barat Tahun 2019-2039, Perda Provinsi Kalimantan Barat No. 1 Tahun 2019, LD Provinsi Kalimantan Barat Tahun 2019 No. 1, No. Reg Perda Provinsi Kalimantan Barat: 1-6/2019, TLD Provinsi Kalimantan Barat No. 1, Pasal 17 ayat (2) dan Lampiran III angka 5.

${ }^{18}$ Provinsi Jawa Timur, Peraturan Daerah Provinsi Jawa Timur No. 1 Tahun 2018 tentang Rencana Zonasi Wilayah Pesisir dan Pulau-Pulau Kecil Provinsi Jawa Timur Tahun 2018-2038, Perda Provinsi Jawa Timur No. 1 Tahun 2018, LD Provinsi Jawa Timur Tahun 2018 No. 1 Seri D, No. Reg Perda Provinsi Jawa Timur: 1/7/2018, TLD Provinsi Jawa Timur No. 79, Pasal 10 ayat (2) huruf b, Pasal 12 ayat (1) huruf c, Pasal 12 ayat (4) huruf a dan b, Pasal 35 ayat (1) huruf a, Pasal 42 huruf c, Pasal 47 - 49 dan Lampiran II.

${ }^{19}$ Provinsi Jawa Tengah, Peraturan Daerah Provinsi Jawa Tengah No. 13 Tahun 2018 tentang Rencana Zonasi Wilayah Pesisir dan Pulau-Pulau Kecil Provinsi Jawa Tengah Tahun 2018-2038, Perda Provinsi Jawa Tengah No. 13 Tahun 2018, LD Provinsi Jawa Tengah Tahun 2018 No. 13, No. Reg Perda Provinsi Jawa Tengah: 13-302/2018, TLD Provinsi Jawa Tengah No. 105, Pasal 13 ayat (2) huruf c, Pasal 31 huruf c, Pasal 34 dan Lampiran III angka 3. 
Dalila Doman

Kesesuaian Pengaturan Pemanfaatan Zona Migrasi Biota Laut dalam PeraturanPeraturan Daerah Provinsi dengan UU tentang Pengelolaan Wilayah Pesisir dan PulauPulau Kecil (UU WP3K)

lawesi Tenggara ${ }^{20}$, Perda RZWP3K Provinsi Sulawesi Tengah, ${ }^{21}$ Perda RZWP3K Provinsi Sulawesi Selatan, ${ }^{22}$ Perda RZWP3K Provinsi Sulawesi Barat, ${ }^{23}$ Perda RZ-
WP3K Provinsi Maluku Utara, ${ }^{24}$ Perda RZWP3K Provinsi Maluku, ${ }^{25}$ Perda RZWP3K Provinsi Lampung, ${ }^{26}$ Perda RZWP3K Provinsi Kalimantan Utara, ${ }^{27}$ Perda

${ }^{20}$ Provinsi Sulawesi Tenggara, Peraturan Daerah Provinsi Sulawesi Tenggara No. 9 Tahun 2018 tentang Rencana Zonasi Wilayah Pesisir dan Pulau-Pulau Kecil Provinsi Sulawesi Tenggara Tahun 2018-2038, Perda Provinsi Sulawesi Tenggara No. 13 Tahun 2018, LD Provinsi Sulawesi Tenggara Tahun 2018 No. 9, No. Reg Perda Provinsi Sulawesi Tenggara: 9-332/2018, Pasal 7 ayat (1) huruf c, Pasal 9 ayat (2) huruf b, Pasal 23 ayat (1) huruf c, Pasal 23 ayat (4) huruf a-c, Pasal 39 ayat (3) huruf a angka 1, Pasal 42, Pasal 45.

${ }^{21}$ Provinsi Sulawesi Tengah, Peraturan Daerah Provinsi Sulawesi Tengah No. 10 Tahun 2017 tentang Rencana Zonasi Wilayah Pesisir dan Pulau-Pulau Kecil Provinsi Sulawesi Tengah Tahun 2017-2037, Perda Provinsi Sulawesi Tengah No. 10 Tahun 2017, LD Provinsi Sulawesi Tengah Tahun 2017 No. 100, No. Reg Perda Provinsi Sulawesi Tengah: 10/317/2017, Pasal 9 ayat (7) huruf c, Pasal 31 ayat (1), Pasal 34, Pasal 45 ayat (3) huruf a, Pasal 46 ayat (2) huruf a dan Pasal 59 ayat (1), (2), (7), (8), (9) dan (10) huruf e.

${ }^{22}$ Provinsi Sulawesi Selatan, Peraturan Daerah Provinsi Sulawesi Selatan No. 2 Tahun 2019 tentang Rencana Zonasi Wilayah Pesisir dan Pulau-Pulau Kecil Provinsi Sulawesi Selatan Tahun 2019-2039, Perda Sulawesi Selatan No. 2 Tahun 2019, LD Provinsi Sulawesi Selatan Tahun 2019 No. 2, No. Reg Perda Provinsi Sulawesi Selatan: 2-107/2019, TLD Provinsi Sulawesi Selatan No. 302, Pasal 12 ayat (6) huruf c, Pasal 29 ayat (4) huruf a, Pasal 33 ayat (1), Pasal 36, Pasal 46 ayat (3) huruf e, Pasal 47 ayat (3) huruf a, Pasal 61 ayat (3) huruf d, Pasal 61 ayat (4) huruf j, Pasal 62 ayat (1), Pasal 62 ayat (5) huruf e dan Pasal 64.

${ }^{23}$ Sulawesi Barat, Peraturan Daerah Provinsi Sulawesi Barat No. 6 Tahun 2017 tentang Rencana Zonasi Wilayah Pesisir dan Pulau-Pulau Kecil Provinsi Sulawesi Selatan Tahun 2017-2037, Perda Sulawesi Barat No. 6 Tahun 2017, LD Provinsi Sulawesi Selatan Tahun 2017 No. 6, No. Reg Perda Provinsi Sulawesi Barat: 6/254/2017, TLD Provinsi Sulawesi Barat No. 85, Pasal 12 ayat (1) huruf c, Pasal 13 ayat (4), Pasal 26 ayat (2) huruf a, Pasal 31 ayat (2) huruf d, Pasal 34 ayat 91) huruf c, Pasal 34 ayat (2), Pasal 34 ayat (3) huruf c, Pasal 34 ayat (4) huruf c, Pasal 34 ayat (5) huruf c, Pasal 42, Pasal 55 ayat (2) huruf d, Pasal 55 ayat (3) huruf c, Pasal 56 ayat (1), Pasal 58 dan Pasal 84 huruf c, d dan f.

${ }^{24}$ Maluku Utara, Peraturan Daerah Provinsi Maluku Utara No. 2 Tahun 2018 tentang Rencana Zonasi Wilayah Pesisir dan Pulau-Pulau Kecil Provinsi Maluku Utara Tahun 2018-2038, Perda Maluku Utara No. 2 Tahun 2018, LD Provinsi Maluku Utara Tahun 2018 No. 2, No. Reg Perda Provinsi Maluku Utara: 2-182/2018, TLD Provinsi Maluku Utara No. 2, Pasal 10 ayat (4) huruf c, Pasal 25 ayat (1) huruf c, Pasal 25 ayat (2) huruf c, Pasal 32 ayat (1) huruf a dan b, Pasal 32 ayat (3), Pasal 45 ayat (2) huruf a, Pasal 45 ayat (3) huruf c, Pasal 47 ayat (1) dan Pasal 49.

${ }^{25}$ Maluku, Peraturan Daerah Provinsi Maluku No. 1 Tahun 2018 tentang Rencana Zonasi Wilayah Pesisir dan Pulau-Pulau Kecil Provinsi Maluku Tahun 2018-2038, Perda Maluku No. 1 Tahun 2018, LD Provinsi Maluku Tahun 2018 No. 150, No. Reg Perda Provinsi Maluku: 1-168/2018, TLD Provinsi Maluku No. 140, Pasal 14 ayat (6), Pasal 37 ayat (1) huruf c, Pasal 37 ayat (2), Pasal 37 ayat (3) huruf c, Pasal 37 ayat (4) huruf c, Pasal 37 ayat (7), Pasal 39, Pasal 56 ayat (3) huruf I, Pasal 56 ayat (4) huruf g, Pasal 56 ayat (5) huruf c, Pasal 60 dan Pasal 85 huruf c, d, dan f .

${ }^{26}$ Lampung, Peraturan Daerah Provinsi Lampung No. 1 Tahun 2018 tentang Rencana Zonasi Wilayah Pesisir dan Pulau-Pulau Kecil Provinsi Lampung Tahun 2018-2038, Perda Lampung No. 1 Tahun 2018, LD Provinsi Lampung Tahun 2018 No. 1, No. Reg Perda Provinsi Lampung: 1/8/2018, Pasal 8 ayat (2) huruf c, Pasal 10 ayat (7), Pasal 27 ayat (1) huruf c, Pasal 28 ayat (3), Pasal 28 ayat (4) huruf e, Pasal 46 ayat (2) huruf a, Pasal 46 ayat (3) huruf a, Pasal 47 ayat (2) huruf b, Pasal 51 ayat (1), Pasal 53 dan Pasal 79 huruf $c$, d dan $\mathrm{f}$.

${ }^{27}$ Kalimantan Utara, Peraturan Daerah Provinsi Kalimantan Utara No. 4 Tahun 2018 tentang Rencana Zonasi Wilayah Pesisir dan Pulau-Pulau Kecil Provinsi Kalimantan Utara Tahun 2018-2038, Perda Kalimantan Utara No. 4 Tahun 2018, LD Provinsi Kalimantan Utara 2018 No. 4, No. Reg Perda Provinsi Kalimantan Utara: 4/136/2018, TLD Provinsi Kalimantan Utara No. 4, Pasal 10 ayat (6), Pasal 26 ayat (1) huruf c, Pasal 26 ayat (2), Pasal 26 ayat (3) huruf c, Pasal 26 ayat (4) huruf c, Pasal 26 ayat (5) huruf c, 
RZWP3K Provinsi Kalimantan Selatan ${ }^{28}$ dan Perda RZWP3K Provinsi Goronta$10,{ }^{29}$ menetapkan migrasi biota laut dalam ketentuan alur laur dan mengatur pemanfaatan zona migrasi biota laut sesuai dengan Pasal 1 angka 14 UU WP3K.

\section{Perda yang Menetapkan Peman- faatan Migrasi Biota Laut dalam Perda RZWP3K Namun Tidak Sesuai dengan Pasal 1 angka 14 UU WP3K}

Perda RZWP3K Sulawesi Utara, Perda RZWP3K Nusa Tenggara Timur, Perda RZWP3K Nusa Tenggara Barat, Perda RZWP3K Kalimantan tengah dan Perda RZWP3K Jawa Barat menetapkan zona migrasi biota laut dalam ketentuan alur laur namun, pengaturan pemanfaatan zona migrasi biota laut kurang sesuai dengan Pasal 1 angka 14 UU WP3K. Berikut penjabarannya:

\section{Tabel 3. Analisis Perda RZWP-3-K yang Tidak Sesuai Ketentuan Pasal 1 angka 14 UU WP-3-K}

\begin{tabular}{|c|c|l|}
\hline No. & Keterangan & \multicolumn{1}{|c|}{ Ketentuan mengenai Migrasi Biota Laut } \\
\hline & Perda Prov. Sula- & Penjelasan Pasal 11 ayat (1) huruf d ${ }^{30}$ dan Pasal 12 ayat (5) huruf c $c^{31}$ \\
& wesi Utara No. 1 & menyatakan migrasi biota laut bagian dari lingkup kawasan alur laut. \\
\cline { 3 - 3 } 1. & Tahun 2017 tentang & \\
& RZWP3K Provinsi & Ketiadaan klausul yang mengatur mengenai kegiatan yang "boleh", "ti- \\
& Sulawesi Utara & dak boleh" dan "hanya dapat dilaksanakan setelah memperoleh izin" . \\
& Tahun 2017-2037. & \\
\hline
\end{tabular}

Pasal 43 ayat (2) huruf a, Pasal 43 ayat (3) huruf c, Pasal 46 dan Pasal 67 huruf c, d, e dan g Perda Prov. Kalimantan Utara No. 4 Tahun 2018 tentang RZWP-3-K Provinsi Kalimantan Utara Tahun 2018-2038.

${ }^{28}$ Kalimantan Selatan, Peraturan Daerah Provinsi Kalimantan Selatan No. 13 Tahun 2018 tentang Rencana Zonasi Wilayah Pesisir dan Pulau-Pulau Kecil Provinsi Kalimantan Selatan Tahun 2018-2038, Perda Kalimantan Selatan No. 13 Tahun 2018, LD Provinsi Kalimantan Selatan 2018 No. 13, No. Reg Perda Provinsi Kalimantan Selatan: 11-145/2018, TLD Provinsi Kalimantan Selatan No. 113, Pasal 9 ayat (1) dan (4), Pasal 25 ayat (1) huruf c, Pasal 28, Pasal 33 ayat (4) huruf d dan Pasal 41 ayat (3), (10), (11), (12).

${ }^{29}$ Jawa Barat, Peraturan Daerah Provinsi Jawa Barat No. 5 Tahun 2019 tentang Rencana Zonasi Wilayah Pesisir dan Pulau-Pulau Kecil Provinsi Jawa Barat Tahun 2019-2039, Perda Jawa Barat No. 5 Tahun 2019, LD Provinsi Jawa Barat 2019 No. 5, No. Reg Perda Provinsi Jawa Barat: 4-40/2019, TLD Provinsi Jawa Barat No. 234, Pasal 15 ayat (6) huruf c, Pasal 31 ayat (1), Pasal 34, Pasal 45 ayat (3) huruf a, Pasal 52 ayat (2) huruf f, Pasal 52 ayat (3) huruf d dan Pasal 53 ayat (1), (8), (9), (10) dan (11) huruf f Perda Prov. Gorontalo No. 4 Tahun 2018 tentang RZWP-3-K Provinsi Jawa Barat Tahun 2018-2038.

30 "Alur laut merupakan perairan yang dimanfaatkan antara lain, untuk alur pelayaran, pipa/kabel bawah laut, dan migrasi biota laut.".

31 "Alur Laut sebagaimana dimaksud pada pasal 11 ayat (1) huruf d terdiri atas: c. migrasi biota laut. 
Kesesuaian Pengaturan Pemanfaatan Zona Migrasi Biota Laut dalam PeraturanPeraturan Daerah Provinsi dengan UU tentang Pengelolaan Wilayah Pesisir dan PulauPulau Kecil (UU WP3K)

\begin{tabular}{|c|c|c|}
\hline \multirow[b]{2}{*}{2.} & \multirow{2}{*}{$\begin{array}{l}\text { Perda Prov. Nusa } \\
\text { Tenggara Timur } \\
\text { No. 4 Tahun 2017 } \\
\text { tentang RZWP3K } \\
\text { Prov. Nusa Teng- } \\
\text { gara Timur Tahun } \\
\text { 2017-2037 }\end{array}$} & $\begin{array}{l}\text { Pasal } 11 \text { ayat }(4)^{32} \text { dan Pasal } 19 \text { ayat }(1) \text { huruf } h^{33} \text { menyatakan migrasi } \\
\text { biota laut sebagai bagian dari lingkup kawasan alur laut. }\end{array}$ \\
\hline & & $\begin{array}{l}\text { Pasal } 31 \text { yang mengatur mengenai "Ketentuan Umum Pemanfaatan } \\
\text { Alur Laut" pada ayat (1) huruf a: } \\
\text { "Kegiatan yang boleh dilakukan di Alur Laut sebagaimana dimaksud } \\
\text { dalam Pasal } 11 \text { ayat (1) huruf c, terdiri atas: } \\
\text { a. Lalu lintas kapal dari dan/atau menuju pelabuhan;" }\end{array}$ \\
\hline \multirow[b]{2}{*}{3.} & \multirow{2}{*}{$\begin{array}{l}\text { Perda Prov. Nusa } \\
\text { Tenggara Barat No. } \\
12 \text { Tahun } 2017 \text { ten- } \\
\text { tang RZWP3K Pro- } \\
\text { vinsi Nusa Teng- } \\
\text { gara Barat Tahun } \\
\text { 2017-2037 }\end{array}$} & $\begin{array}{l}\text { Pasal } 13 \text { ayat (1) huruf } c^{34} \text { dan Pasal } 47 \text { ayat (1) huruf } c^{35} \text { menyatakan bah- } \\
\text { wa migrasi biota laut merupakan bagian dari lingkup kawasan alur laut. }\end{array}$ \\
\hline & & $\begin{array}{l}\text { Ketentuan Pasal } 66 \text { yang mengatur mengenai “Pengendalian pemanfaat- } \\
\text { an Alur Laut" hanya ditetapkan sebagai berikut: } \\
\text { "Pemberian tanda khusus pada daerah migrasi biota laut;", }\end{array}$ \\
\hline \multirow[b]{2}{*}{4.} & \multirow{2}{*}{$\begin{array}{l}\text { Perda Prov. Ka- } \\
\text { limantan Tengah } \\
\text { No. 1 Tahun 2019 } \\
\text { tentang RZWP3K } \\
\text { Provinsi Kaliman- } \\
\text { tan Tengah Tahun } \\
\text { 2019-2039 }\end{array}$} & biota laut sebagai bag \\
\hline & & $\begin{array}{l}\text { Pasal } 43 \text { yang mengatur mengenai "Peraturan Pemanfaatan Ruang Mi- } \\
\text { grasi Biota Laut" hanya mengatur bahwa pemanfaatan ruang migrasi } \\
\text { biota dilaksanakan dengan cara inventarisasi jenis dari biota-biota laut } \\
\text { yang melakukan migrasi pada kawasan perairan. }\end{array}$ \\
\hline \multirow[b]{2}{*}{5.} & \multirow[b]{2}{*}{$\begin{array}{l}\text { Perda Prov. Jawa } \\
\text { Barat No. } 5 \text { Tahun } \\
2019 \text { tentang RZW- } \\
\text { P3K Provinsi Jawa } \\
\text { Barat Tahun 2019- } \\
2039^{39}\end{array}$} & biota laut sebagai bag \\
\hline & & $\begin{array}{l}\text { Pasal } 75 \text { yang mengatur mengenai "Pemanfaatan Ruang pada Migrasi } \\
\text { Biota Laut" pada ayat (3) huruf a menyatakan: } \\
\text { “Kegiatan yang diperbolehkan setelah memperoleh izin untuk AL-MB } \\
\text { (Alur Laut Migrasi Biota Laut), seperti: } \\
\text { a. lalu lintas kapal dengan kecepatan tinggi; ...”. }\end{array}$ \\
\hline
\end{tabular}

32 "Alur Laut sebagaimana dimaksud pada ayat (1) huruf c, meliputi Alur Lintas Kepulauan Indonesia, Alur pelayaran, Pipa/Kabel Bawah Laut dan migrasi biota laut.".

33 "Alur laut yang dimaksud pada Pasal 11 ayat (4), meliputi: h. Alur migrasi biota laut.".

34 "Kebijakan pengembangan alur laut sebagaimana dimaksud dalam Pasal 10 huruf c, meliputi: c. penetapan dan pelindungan alur migrasi biota laut.".

35 "Alur laut sebagaimana dimaksud dalam Pasal 15 ayat (1) huruf c terdiri atas: c. alur migrasi biota laut.".

${ }^{36}$ Pasal 11 ayat (1) huruf c, Pasal 11 ayat (4), Pasal 24 huruf c, Pasal 27, Pasal 39 huruf c, Pasal 43,

37 "Kebijakan pengembangan alur laut sebagaimana dimaksud dalam Pasal 8 huruf c dilakukan melalui upaya menjaga keselamatan pada kawasan alur laut, terdiri atas: c. Migrasi biota laut.".

38 "Alur laut sebagaimana yang dimaksud pada pasal 13 ayat 91) huruf c adalah bagian dari wilayah pesisir yang ditetapkan peruntukannya bagi berbagai sektor kegiatan yang terdiri atas: c. Migrasi Biota Laut yang selanjutnya disebut AL-AMB".

${ }^{39}$ Jawa Barat, Peraturan Daerah Provinsi Jawa Barat No. 5 Tahun 2019 tentang Rencana Zonasi Wilayah Pesisir dan Pulau-Pulau Kecil Provinsi Jawa Barat Tahun 2019-2039, Perda Jawa Barat No. 5 Tahun 2019, LD Provinsi Jawa Barat 2019 No. 5, No. Reg Perda Provinsi Jawa Barat: 4-40/2019, TLD Provinsi Jawa Barat No. 234, Pasal 7 huruf d angka 3, Pasal 21, Pasal 42 huruf d, Pasal 47 dan pasal 75.

40 "Kebijakan pemanfaatan dan pengembangan alokasi ruang, meliputi: d. pengelolaan alur laut terdiri dari: 3. Perlindungan migrasi biota laut.".

41 "Alur Laut sebagaimana dimaksud dalam Pasal 22 ayat (1) huruf d, meliputi: d. Migrasi Biota Laut yang selanjutnya disebut AL-MB.". 
Perda Prov. Nusa Tenggara Timur No. 4 Tahun 2017 tentang RZWP3K Prov. Nusa Tenggara Timur Tahun 20172037 dan Perda Prov. Jawa Barat No. 5 Tahun 2019 tentang RZWP3K Provinsi Jawa Barat Tahun 2019-2039 mengatur kegiatan "hanya dapat dilakukan setelah memperoleh izin" di zona migrasi biota laut yakni "lalu litas kapal dengan kecepatan tinggi". Lalu lintas kapal dengan kecepatan tinggi di zona migrasi biota laut seharusnya tidak diperbolehkan sekalipun setelah memperoleh izin. Hal tersebut dikarenakan berdasarkan penelitian Henry P. Huntington, dalam "Vessel Risks and Rules: Planning for Safe Shipping in Bering Strait" aturan mengenai kecepatan kapal berpengaruh besar untuk mengurangi implikasi dan risiko atas hewan salah satunya mamalia laut seperti paus (cetacean) tertabrak kapal. ${ }^{42}$

\section{Konsekuensi Hukum Ketentu-} an Pemanfaatan Zona Migrasi Biota Laut dalam Perda RZWP3K yang Tidak Sesuai dengan Pasal 1 angka 14 UU WP3K

Zona migrasi biota laut merupakan bagian dari kawasan perencanaan yakni kawasan alur laut, sehingga zona migrasi biota laut termasuk dalam lingkup "kawasan perencanaan" yang dimaksud dalam redaksi Pasal 1 angka 14 UU WP3-K. Pasal 1 angka 14 UU WP-3-K memiliki redaksi:

“Rencana Zonasi adalah rencana yang menentukan arah penggunaan sumber daya tiap-tiap satuan perencanaan disertai dengan penetapan struktur dan pola ruang pada Kawasan perencanaan yang memuat kegiatan yang boleh dilakukan dan tidak boleh dilakukan serta kegiatan yang hanya dapat dilakukan setelah memperoleh izin."

Selanjutnya, diketahui bahwa tidak ada kata "harus" atau "wajib" sebelum kalimat "yang memuat kegiatan yang boleh dilakukan dan tidak boleh dilakukan serta kegiatan yang hanya dapat dilakukan setelah memperoleh izin". Ketiadaan kata "harus" atau "wajib" tersebut menjadikan sifat Pasal 1 angka 14 UU WP3K hanya menganjurkan atau mengarahkan, ${ }^{43}$ sehingga tidak ada konsekuensi hukum tegas untuk Perda RZWP3K yang tidak mengatur secara spesifik mengenai kegiatan dalam pemanfaatan zona migrasi biota laut ke dalam golongan kegiatan "boleh", "tidak boleh dilakukan" dan "kegiatan yang hanya dapat dilakukan setelah memperoleh izin" sebagaimana arahan Pasal 1 angka 14 UU WP3K. Walaupun

\footnotetext{
${ }^{42}$ Henry P. Huntington, Raychelle Daniel, dkk, Vessels, Risks and Rules: Planning for safe Shipping in Bering Strait, Jurnal Elsevier, Marine Policy 51 (2015), hlm. 119-127, 6 September 2014, hlm. 123,

https://reader.elsevier.com/reader/sd/pii/S0308597X14002012?token=DD3266E2F7DF90AF7FA6EF43D757B9E5C52E9BF29D0B6C5AA77E38DA1398B910B18439AA0186356AB4F0487CCB807B58, diakses pada 19 Desember 2019.

${ }^{43}$ Indonesia, Undang-Undang No. 12 tahun 2011 tentang Pembentukan Peraturan Perundang-Undangan,
} 
Kesesuaian Pengaturan Pemanfaatan Zona Migrasi Biota Laut dalam PeraturanPeraturan Daerah Provinsi dengan UU tentang Pengelolaan Wilayah Pesisir dan PulauPulau Kecil (UU WP3K)

demikian, ketiadaan pengaturan pemanfaatan zona migrasi biota laut dalam Perda RZWP3K sebagaimana arahan Pasal 1 angka 14 UU WP3K, berpotensi menimbulkan kegagalan Perda RZWP3K dalam melindungi zona migrasi biota laut jika kemudian ada oknum yang bertindak sewenang-wenang (karena ketiadaan penggolongan kegiatan di zona migrasi biota laut) dalam pemanfaatan zona migrasi biota laut. ${ }^{44}$

\section{Kesimpulan}

Sebanyak 22 provinsi hingga November 2019 telah mengesahkan Perda RZWP3K Beberapa Perda RZWP3K menetapkan zona migrasi laut ke dalam ketentuan alur laur. Ketentuan mengenai kegiatan pemanfaatan di zona migrasi biota laut di setiap Perda RZWP3K idealnya sesuai dengan arahan Pasal 1 angka 14 UU WP3K. Zona migrasi biota laut akan terlindung dari kegiatan sewenang-wenang dalam pemanfaatan di zona migrasi biota laut.
Penulis menemukan bahwa lima provinsi tidak menetapkan zona migrasi biota laut ke dalam kawasan alur laut di Perda RZWP3K sedangkan dua belas provinsi dalam Perda RZWP3K mengatur pemanfaatan migrasi biota laut sesuai ketentuan Pasal 1 angka 14 UU WP3K. Namun, lima provinsi mengatur pemanfaatan zona migrasi biota laut kurang sesuai dengan ketentuan Pasal 1 angka 14 UU WP3K. Dibutuhkan kajian lebih jauh untuk mengetahui alasan di balik Perda RZWP3K yang tidak mengatur pemanfaatan zona migrasi biota laut sesuai dengan arahan Pasal 1 angka 14 UU WP3K. Walaupun demikian, tidak ada konsekuensi hukum tegas atas Perda RZWP3K yang tidak mengatur pemanfaatan zona migrasi biota laut sesuai dengan Pasal 1 angka 14 UU WP3K dikarenakan ketiadaan kata "harus" atau "wajib" sebelum kalimat "yang memuat kegiatan yang boleh dilakukan dan tidak boleh dilakukan serta kegiatan yang hanya dapat dilakukan setelah memperoleh izin".

UU No. 12 Tahun 2011, LN Tahun 2011 No. 82, TLN No. 5234, Bab III “Ragam Bahasa Peraturan Perundang-Undangan", Bahasa Peraturan Perundang-Undangan, angka 268.: "Untuk menyatakan adanya suatu kewajiban yang telah ditetapkan, gunakan kata wajib. Jika kewajiban tersebut tidak dipenuhi, yang bersangkutan dijatuhi sanksi.", lihat juga Sri Hariningsih SH., MH., Perumusan Norma dalam Peraturan Perundang-Undangan, Kementerian Hukum dan HAM, hlm.4, http://ditjenpp.kemenkumham. go.id/files/doc/1944_Perumus\%20Norma\%20dalam\%20Peraturan\%20Perundang-undangan.pdf, diakses pada 2 Desember 2019

${ }^{44}$ Dewan Perwakilan Rakyat Indonesia, Proses Pembahasan Rancangan Undang-Undang tentang Pengelolaan Wilayah Pesisir dan Pulau-Pulau Kecil: Buku 1, Sekretariat Jenderal Dewan Perwakilan Rakyat Republik Indonesia, 2008, hlm. 1133. 